\title{
Market and Non-market Factors Influencing Farmers' Adoption of Improved Beef Cattle in Arid and Semi-Arid Areas of Kenya
}

\author{
David Jakinda Otieno ${ }^{1}$ \\ ${ }^{1}$ Department of Agricultural Economics, University of Nairobi, Kenya \\ Correspondence: David Jakinda Otieno, Department of Agricultural Economics, University of Nairobi, Kenya. \\ E-mail: jakinda1@yahoo.com
}

Received: September 17, 2012 Accepted: October 9, 2012 Online Published: December 13, 2012

doi:10.5539/jas.v5n1p32

URL: http://dx.doi.org/10.5539/jas.v5n1p32

\begin{abstract}
This study assessed various market and non-market factors that might have a considerable bearing on farmers' adoption of improved beef cattle breeds in dry areas of Kenya. A binomial (binary) logit model was applied to analyse survey data from a multistage area sample of beef cattle farmers. Results showed that about $53 \%$ of farmers in the arid and semi-arid areas of Kenya have adopted improved beef cattle. The main factors that were found to have significant influence on farmers' probability of adoption of improved beef cattle are peri-urban location, sale of cattle to abattoirs rather than in open air markets, and practise of agro-pastoral or ranch production systems. On the contrary, practice of nomadic production system, possession of experience in cattle production and larger farms did not have a favourable influence on adoption of improved cattle breeds. These findings offer important insights to development policy on provision of requisite services and institutional support in order to enhance the adoption of improved cattle breeds for better livelihoods in the typically resource-constrained arid and semi-arid areas.
\end{abstract}

Keywords: market and non-market factors, improved beef cattle, adoption, Kenya

\section{Introduction}

Livestock production supports the livelihood of many households in the world, especially in Africa through provision of diverse outputs, including food, manure, draught power and acts as an important investment sink that generates cash for socio-economic needs e.g., school fees and medical bills. It is estimated that on average, livestock contribute about $30 \%$ of agricultural gross domestic product (GDP) in sub-Saharan Africa (SSA) and directly supports $10 \%$ of the human population and another $58 \%$ indirectly (African Union Interafrican Bureau for Animal Resources [AU-IBAR], 2010). In Kenya where $80 \%$ of land is marginal or arid and semi-arid land (ASAL), livestock enterprises, especially beef cattle production are often the most viable options in such areas. The livestock enterprises provide employment to $90 \%$ of the population in the ASALs and contribute $95 \%$ of the household income in those areas (Otieno, 2008; Kenya Institute for Public Policy Research and Analysis [KIPPRA], 2009). There are about 9.5 million beef cattle in Kenya; $70 \%$ of these are kept by pastoralists (nomadic pastoralists and agro-pastoralists) in the ASALs, while the rest are either in ranches or integrated in dairy farms (Republic of Kenya, 2010). Generally, livestock contribute nearly $40 \%$ of Kenya's agricultural output; $35 \%$ of this is obtained from beef cattle. However, the annual beef production (estimated to be 445000 metric tonnes in 2007) is considerably lower than domestic consumption requirements (Ministry of Agriculture and Kenya Institute for Public Policy Research and Analysis [MoA \& KIPPRA], 2009).

There are three main beef cattle production systems in the ASALs of Kenya: nomadic pastoralism, agro-pastoralism and ranches. Nomadic pastoralists (also commonly referred to as nomads) are less sedentary and migrate seasonally with cattle and other livestock in search for pasture and water (Fratkin, 2001). They are less commercialised, but derive a relatively large share of their livelihood from cattle and other livestock. Further, Thornton et al. (2007) note that nomads generally maintain cattle principally as a capital and cultural asset, and sell only when absolutely necessary. In contrast, the agro-pastoralists are sedentary; they keep cattle and other livestock, besides cultivating crops, and are relatively commercialised. Finally, ranches are purely commercial livestock enterprises; and may also grow some crops mainly for use as on-farm fodder or for sale. On average, nomads and agro-pastoralists produce two-thirds of total beef output in Kenya (Aklilu, 2002; Omiti \& Irungu, 2002). However, more than $50 \%$ of pastoralists in the ASALs live below the poverty line, i.e., they survive on 
less than USD 1.5 per day (Thornton et al., 2007). The main beef cattle types in Kenya are local breeds (e.g., Zebu \& Boran). These are generally considered to be relatively adapted to low-feed availability, and frequent drought and disease challenges prevalent in SSA. However, local breeds also fetch low market value due to factors such as small body size/low slaughter weight. Further, local breeds are characterised by low growth rates and declining productivity (Kavoi, Hoag, \& Pritchett, 2010).

In order to address declining livestock productivity and rising poverty among the livestock-dependent households, deliberate efforts have previously been made by the Kenya government to improve local breeds (e.g., by promoting crossbreeding of Zebu and Boran to produce the Sahiwal) or through subsidised artificial insemination (AI) services targeting enhanced crossbreeding of local breeds with exotic ones such as Charolais, Simmental and Hereford. Moreover, upon economic liberalisation in Kenya in 1990s, private sector operators, including cooperatives joined the government in the provision of crossbreeding services, especially AI or natural bull services (for details see for instance, Owango, Lukuyu, Staal, Kinyanjui, \& Njubi, 1998; Rege, 1998; Kahi, Thorpe, Nitter, Van Arendonk, \& Gall, 2000; Bebe, Udo, Rowlands, \& Thorpe, 2003; Kahi, Nitter, \& Gall, 2004). However, the major focus of cattle improvement programmes in Kenya has been dairy sub-sector; the beef cattle sub-sector is relatively neglected by policy (Gamba, 2006). Further, there is an extensive literature on adoption of improved cattle breeds by dairy farmers in high potential areas of Kenya (e.g., Tambi, Mukhebi, Maina, \& Solomon, 1999; Kavoi et al., 2010; Musalia, Wangia, Shivairo, \& Vugutsa, 2010; Murage \& Ilatsia, 2011). However, published information on beef cattle farmers' breed choices is very limited (exceptions include Wilson, 2009).

It is important to understand farmers' adoption decisions regarding beef cattle; given that there are considerable differences in resource endowments, relative distribution of institutional support services and ecological conditions between dairy farmers (mostly found in high potential zones) and beef cattle farmers in the ASALs. Generally, beef cattle farmers in the ASALs face numerous challenges including: recurring droughts that lead to frequent scarcity of feed and water, high disease incidence and inadequate veterinary services (Irungu, Omiti, \& Mugunieri, 2006), high human and livestock population pressures, increased competition between agriculture and livestock systems (AU-IBAR, 2010). The ASALs are also characterised by poor infrastructure e.g., bad roads, weak institutional support for provision of inputs such as breeding technology, extension services, inadequate market services and poorly coordinated markets for inputs and outputs (Omiti \& Irungu, 2002). These issues might have a considerable bearing on farmers' decisions regarding the type of beef cattle they keep.

The present study contributes to the literature by investigating market and non-market factors that influence farmers' adoption of improved beef cattle in the arid and semi-arid areas of Kenya. Specific objectives of the study include:

i) to characterise beef cattle farmers in the ASALs of Kenya; and

ii) to analyse market and non-market factors that influence adoption of improved beef cattle in the ASALs of Kenya.

Improved beef cattle are defined in this study as exotic breed or crossbreed either between a local and exotic breed, or among exotic breeds. The study uses farm-household survey data and a binary logit regression model. Insights from the study should guide policies on how to target service provision in order to enhance adoption of improved beef cattle in the marginal zones. It is envisaged that such strategies would serve as important pathways out-of-poverty for the livestock-dependent households in the resource-constrained ASALs.

\section{Methodology}

\subsection{Sampling and Data Collection}

The study was conducted in four sites (Kajiado, Kilifi, Makueni, and Taita Taveta counties) which are representative of the ASALs where most livestock, especially beef cattle in Kenya are kept. Generally, Kenya is divided into seven agro-climatic zones based on moisture index, i.e., the annual rainfall as a percentage of potential evaporation (Sombroek, Braun, \& van de Pouw, 1982). Places with moisture index above $50 \%$ are classified as zones I, II and III, and are considered to have high potential for agriculture. Less than $20 \%$ of land in Kenya falls in the first three categories. The study sites represent different agro-climatic zones, but are close to each other (contiguous), hence logistically more accessible.

Kajiado is classified into zone VI, which include semi-arid to arid rangelands. It borders the capital city, Nairobi, to the north, and the United Republic of Tanzania, to the south. The mean annual rainfall in the area ranges from $300-800 \mathrm{~mm}$, with a moisture index of $25-40 \%$ (Orodho, 2002). However, rainfall in Kajiado is highly variable within and between years, and there are frequent droughts in the area (Thornton et al., 2007). Kajiado is relatively 
close to the central AI centre in Kabete, Nairobi; this might be expected to influence farmers' decision on adoption of improved beef cattle. The study sites are shown in Figure 1.

Kilifi is a semi-humid region (zone III) within Kenya's coastal strip near the Indian Ocean. It has an annual rainfall between $760-1300 \mathrm{~mm}$ and moisture index of about $65 \%$. The area is mainly characterised by ranches and tree-crops including coconuts, cashew nuts and mangoes (Republic of Kenya, 2008a). Kilifi has a generally wet vegetation and hot climate. Makueni is a semi-arid area (zone V), with average rainfall of $500-760 \mathrm{~mm}$ and $40 \%$ moisture index annually. In this area, there is some dry-land irrigated crop farming focusing on production of fruits and vegetables (Republic of Kenya, 2008b). Makueni hosts a national livestock breeding centre for drylands in Kenya, i.e., the Kenya Agricultural Research Institute (KARI)-Kiboko centre; this is expected to increase farmers' access to improved cattle genetic material. Finally, Taita Taveta is a coastal hinterland, classified as semi-humid to semi-arid (zone IV). On average, this site is estimated to have $500-750 \mathrm{~mm}$ of annual rainfall and about $50 \%$ moisture index (Republic of Kenya, 2008c). Generally, Makueni is a transition zone sandwiched between very dry parts of Kajiado and relatively wetter coastal sites.

A multi-stage cluster (area) sampling approach (Horppila \& Peltonen, 1992) was used in the present study. This method is appropriate in situations where the population is scattered over a large geographic area and there is no comprehensive list of the sampling units or sampling frame (as is the case in Kenya). Further, multi-stage cluster (area) sampling is preferred due to its relative convenience, economy and efficiency compared to other sampling techniques. Moreover, the use of probability methods such as random sampling to derive the final sampling units improves the precision of the estimates, ensures representativeness and permits hypothesis tests (Allen et al., 2002).

Within the four districts, smaller administrative units (divisions) were randomly selected from lists of all divisions in these districts, taking into account the general distribution of cattle in the study area. Subsequent stages involved a random selection of a sample of locations, from which a number of smaller units (sub-locations) were selected. The primary sampling units for the survey were therefore forty sub-locations. Systematic random sampling was used to select individual respondents for study. Data were collected through household surveys using a structured questionnaire that was administered through face-to-face interviews. A total of 313 farmers were interviewed.

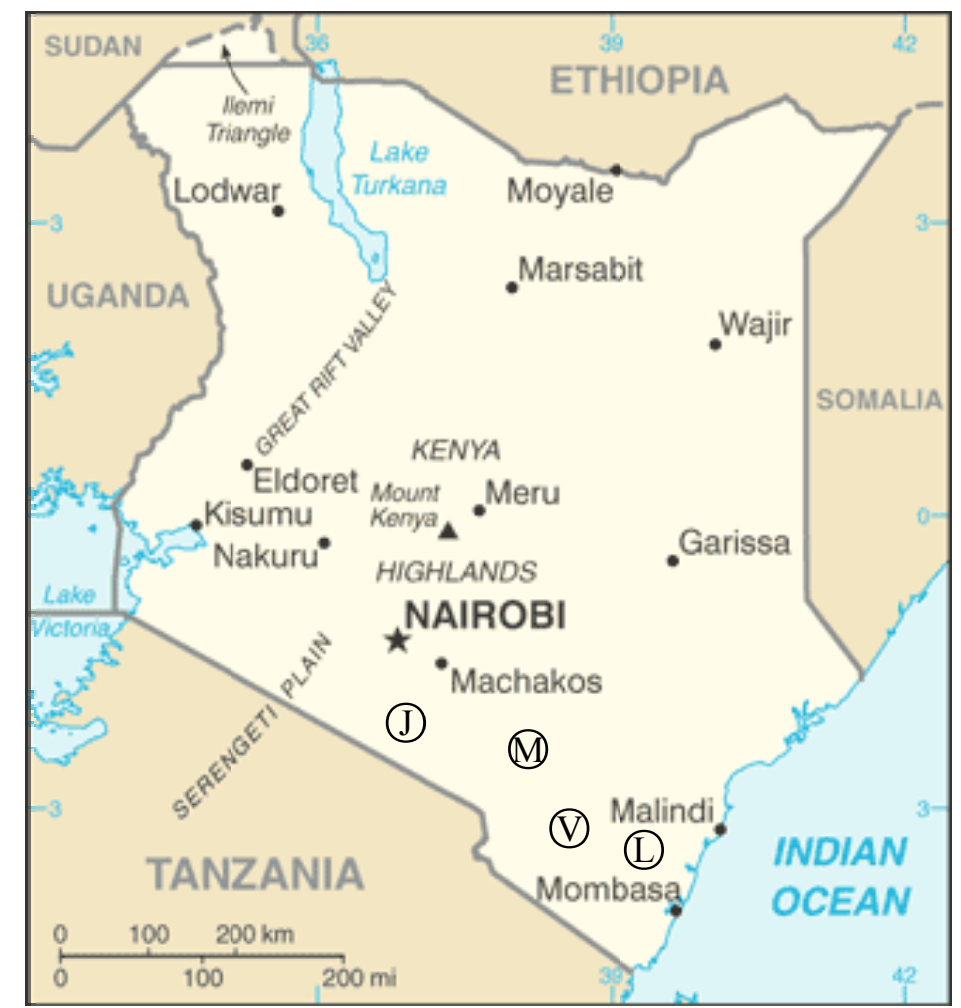

Figure 1. Distribution of the study sites in Kenya (denoted by letters $J, L, M$ and $V$, respectively for Kajiado, Kilifi, Makueni and Taita Taveta)

Source: Adapted from World Atlas (2011). 


\subsection{Theoretical Framework}

Farmers' decisions to adopt different technologies (such as improved cattle breeds) can be modelled within the consumer utility theory, which posits that given a set of options, rational individuals are expected to choose the alternative that they consider to offer maximum utility (satisfaction) than the rest (McFadden, 1974). Some of the potential benefits expected from adoption of improved beef cattle include increased output and productivity, i.e., better slaughter weight, high growth rates and high market value. However, household decision-making on adoption of technologies is often hampered by various constraints (Sadoulet \& de Janvry, 1995).

In the case of Kenya, numerous weather-related challenges such as recurrent droughts and high disease incidence, coupled with institutional bottlenecks (including inadequate veterinary advisory and extension services, inadequate market services, and poor coordination of input and output markets) might have considerable influence on farmers' behaviour regarding adoption of improved cattle. Figure 2 illustrates farmer decision making on technology adoption. It is posited in this study that appropriate policy changes targeting various market and non-market factors would enhance adoption of improved cattle in Kenya.

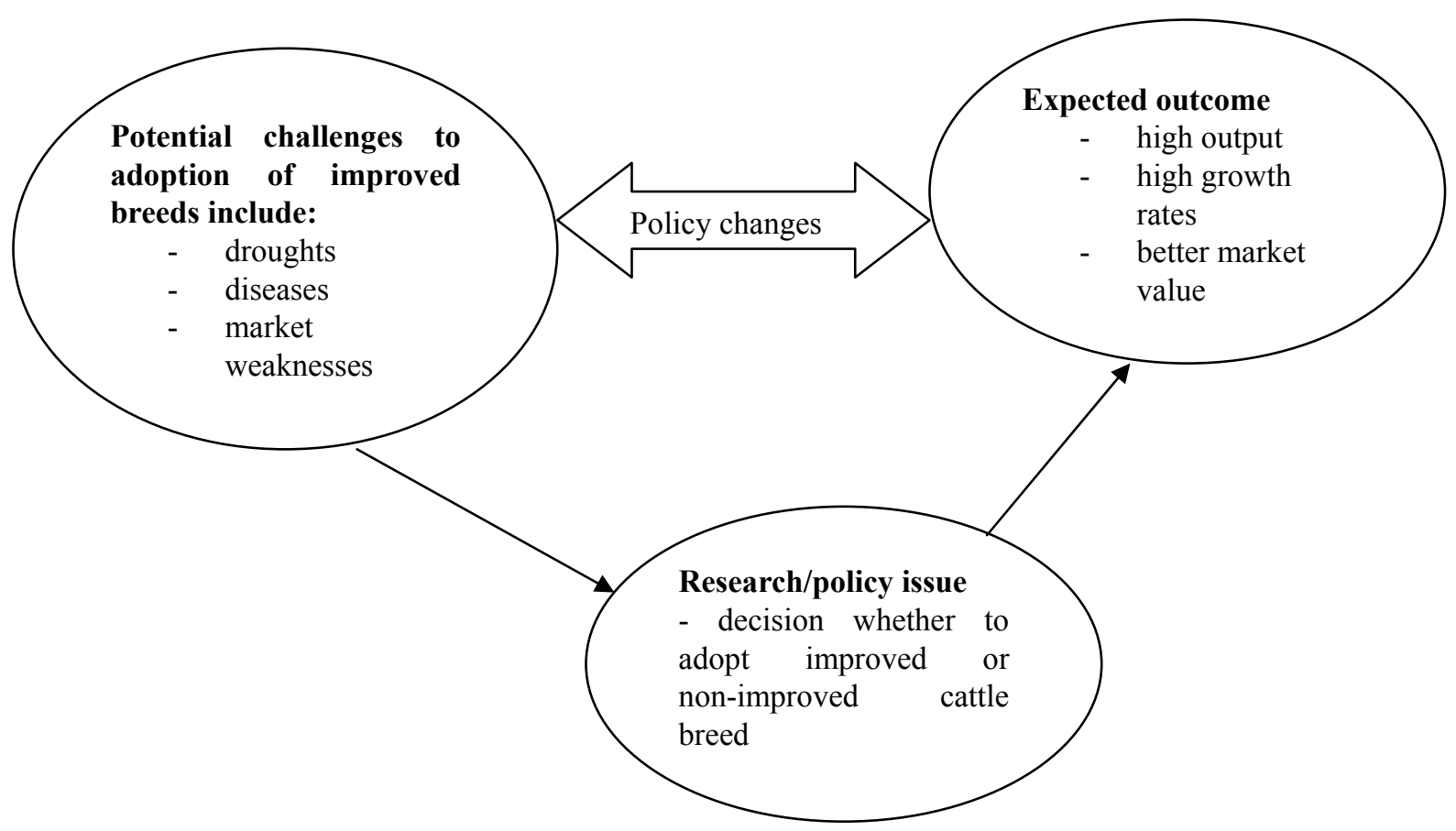

Figure 2. Farmers' adoption decisions on improved cattle in Kenya

Source: Author's conceptualization

\subsection{Model Estimation}

A binary (binomial) logit model was applied to investigate determinants of farmers' probability to adopt improved beef cattle. This is considered to be the most appropriate model given that the dependent variable is discrete and dichotomous, i.e., use of improved cattle or local breed (for details on logit models, see Greene, 2003). Following McFadden (1974) the model is specified as:

$$
\operatorname{Prob}\left[Y_{i j}=1\right]=\frac{\exp \left(\beta^{\prime} x_{i}\right)}{1+\exp \left(\beta^{\prime} x_{i}\right)}=\Lambda\left(\beta^{\prime} x_{i}\right)
$$

The subscripts $i$ and $j$ denote farmer and cattle breed ( $1=$ improved breed, $0=$ local breed), respectively. Equation (1) is the reduced form of the binomial logit model, where the $x_{i}$ row vector of explanatory variables for $i^{\text {th }}$ farmer are the independent variables and the non-observed $\varepsilon$ 's are assumed to follow a distribution of logistic probability with a density function ${ }^{\text {Note }}$ :

$$
F^{\prime}\left(\beta^{\prime} x_{i}\right)=\Lambda\left(\beta^{\prime} x_{i}\right)\left[1-\Lambda\left(\beta^{\prime} x_{i}\right)\right]
$$


Empirically, the model was estimated as:

$$
\operatorname{Pr}\left[C A R B_{i}=1\right]=\beta_{i} X_{i}+\varepsilon_{i}
$$

where $C A B R$ is the type of cattle kept by the $i^{\text {th }}$ farmer (1=improved beef cattle, $0=$ local breed); $X$ is a vector of market and non-market factors that are posited to influence farmers' decision to adopt improved cattle; $\beta_{i}$ is a vector of parameters to be estimated, while $\varepsilon$ is the statistical random term.

Further, marginal effects were estimated to measure instantaneous effects of changes in any explanatory variable on the predicted probability of adoption of improved cattle, holding other explanatory variables constant. The marginal effects are computed as:

$$
\begin{array}{r}
\beta_{m}=\left[\frac{\partial\left(\beta_{i} X_{i}+\varepsilon_{i}\right)}{\partial \beta_{i} X_{i}}\right] \beta_{i} \text { for continuous independent variables } \\
\text { or } \beta_{m}=\operatorname{Pr}\left[C A B R_{i}=1\right]-\operatorname{Pr}\left[C A B R_{i}=0\right] \text { for dummy-coded variables. }
\end{array}
$$

The binary logit model and marginal effects were estimated using LIMDEP version 9.0/NLOGIT version 4.0 software (Greene, 2007).

\section{Results and Discussion}

\subsection{Farm Characteristics}

Some important farm characteristics are summarised in Table 1 . The average herd size and farm size are 56 animals and 124 acres, respectively in the sample of Kenyan beef farmers. About 53\% of farmers in the ASALs have adopted improved beef cattle. Farmers with improved cattle have relatively smaller herds, but larger farms; perhaps due to high management costs and feed requirements associated with improved cattle. A majority of adopters of improved cattle are agro-pastoralists (who also usually operate other enterprises, besides keeping livestock); less diversified farmers (especially nomads who are less sedentary and typically derive a high proportion of their livelihood from livestock) and mainly keep local cattle breeds. Generally, exotic or crossbreed cattle are less hardy, and might not withstand long distance trekking (in search of pasture and/or water), which is a common feature in nomadic pastoralism. On average, the sample comprises farmers with about 14 years of experience in livestock keeping; information obtained from these farmers is therefore considered to be a reliable account of their production decisions.

Despite their close proximity to research centres for livestock breeding, farmers in Kajiado and Makueni have relatively low levels of adoption of improved cattle. Perhaps, this might be explained by the relatively dry and hot climate in both areas (agro-climatic zones V and VI); hence their likely preference for local breeds that are well adapted to limited pasture and water supply, and harsh conditions in those areas. This is consistent with the view of Gamba (2006) that the Zebu is relatively adapted to lowland areas due to its tolerance to drought, disease and low feed intake. In contrast, farmers in relatively wet coastal sites (Kilifi and Taita Taveta in zones III and IV, respectively) have significantly higher adoption levels of improved cattle. Generally, these results accord with the observation by Rege (1998) and Kahi et al. (2000) that exotic cattle or their cross breeds are less adapted to numerous tropical stresses (e.g., poor feed availability and quality, disease and excess heat levels) in drier parts of SSA. 
Table 1. Sample characteristics from the survey

\begin{tabular}{|c|c|c|c|}
\hline Variable & $\begin{array}{l}\text { Improved cattle } \\
\text { adopters }(n=165)\end{array}$ & $\begin{array}{l}\text { Non-adopters of improved } \\
\text { cattle }(\mathrm{n}=148)\end{array}$ & $\begin{array}{l}\text { Pooled sample } \\
\quad(\mathrm{n}=313)\end{array}$ \\
\hline Average herd size & $44.2^{\mathrm{b}}$ & $68.0^{\mathrm{a}}$ & 55.5 \\
\hline $\begin{array}{l}\text { Average number of years of experience in cattle } \\
\text { production }\end{array}$ & $14.7^{\mathrm{a}}$ & $13.4^{\mathrm{a}}$ & 14.1 \\
\hline Average farm size in acres & $130.5^{\mathrm{a}}$ & $116.0^{\mathrm{b}}$ & 123.6 \\
\hline Peri-urban location ( $\%$ of farmers) & $34.5^{\mathrm{a}}$ & $17.6^{\mathrm{b}}$ & 26.5 \\
\hline \multicolumn{4}{|l|}{ Production system ( $\%$ of farmers): } \\
\hline Nomads & $21.2^{\mathrm{b}}$ & $50.7^{\mathrm{a}}$ & 35.1 \\
\hline Agro-pastoralists & $60.6^{\mathrm{a}}$ & $25.0^{\mathrm{b}}$ & 43.8 \\
\hline Ranchers & $18.2^{\mathrm{a}}$ & $24.3^{\mathrm{a}}$ & 21.1 \\
\hline $\begin{array}{l}\text { Access to livestock extension services in the past } \\
\text { year ( } \% \text { of farmers })\end{array}$ & $48.5^{\mathrm{a}}$ & $50.0^{\mathrm{a}}$ & 49.2 \\
\hline $\begin{array}{l}\text { Access to veterinary advisory services in the past } \\
\text { year ( } \% \text { of farmers) }\end{array}$ & $60.0^{\mathrm{a}}$ & $57.4^{\mathrm{a}}$ & 58.8 \\
\hline Household head is male ( $\%$ of farmers) & $69.7^{\mathrm{a}}$ & $73.0^{\mathrm{a}}$ & 71.2 \\
\hline Main market is abattoir ( $\%$ of farmers) & $72.1^{\mathrm{a}}$ & $50.0^{\mathrm{b}}$ & 61.7 \\
\hline $\begin{array}{l}\text { Household head has secondary education or } \\
\text { above ( } \% \text { of farmers) }\end{array}$ & $35.8^{\mathrm{a}}$ & $33.8^{\mathrm{a}}$ & 34.8 \\
\hline $\begin{array}{l}\text { Monthly household income is Kshs } 20000 * \text { or } \\
\text { above (\% of farmers) }\end{array}$ & $29.7^{\mathrm{a}}$ & $35.8^{\mathrm{a}}$ & 32.6 \\
\hline \multicolumn{4}{|l|}{$\begin{array}{l}\text { District/agri-ecological zone (AEZ) }(\% \text { of } \\
\text { farmers) : }\end{array}$} \\
\hline Kajiado (Zone VI ) & $20.6^{\mathrm{b}}$ & $45.3^{\mathrm{a}}$ & 32.3 \\
\hline Kilifi (Zone III ) & $26.7^{\mathrm{a}}$ & $16.9^{\mathrm{b}}$ & 22.0 \\
\hline Makueni (Zone V ) & $9.1^{\mathrm{a}}$ & $9.5^{\mathrm{a}}$ & 9.3 \\
\hline Taita Taveta (Zone IV ) & $43.6^{\mathrm{a}}$ & $28.4^{\mathrm{b}}$ & 36.4 \\
\hline
\end{tabular}

Notes: ${ }^{\mathrm{a}, \mathrm{b}}$ differences in the superscripts denote significant differences (at $10 \%$ level or better) across between adopters and non-adopters of improved cattle. The differences were analysed in MINITAB version 15.0 software, using 2-sample t-tests and 2-proportion tests for continuous variables and discrete binary variables, respectively.

* 75 Kenyan shillings (Kshs) were equivalent to USD 1 at the time of survey.

About half of farmers have access to both livestock extension and veterinary advisory services, and there is no significant difference in access to these between adopters and non-adopters of improved cattle. Only a third of farmers (both adopters and non-adopters of improved cattle) have formal education at secondary level or above, and monthly household income of at least Kshs 20000 . Thus, consistent with the national poverty and literacy estimates (Republic of Kenya, 2010), the sample of beef cattle farmers is relatively poor and has low formal literacy. In addition, majority ( $71 \%$ ) of household heads in beef cattle farms are male.

The main market outlet for cattle is abattoir; $60 \%$ of farmers comprising more than two-thirds of adopters of improved cattle and half of those who keep local cattle breeds sell mainly in abattoirs, than in open air markets. Perhaps, the high preference for abattoirs is due to the possibility of negotiating better prices away from the influence of open market agents/external supply conditions and ability to sell at any time unlike open air markets that only operate on specified days (once or twice a week). Further, most abattoir operators buy at the farm gate; hence farmers save on transportation costs and local authority market charges/sales taxes. As noted by Detre, Mark, Mishra, and Adhikari (2011), direct marketing (e.g., in abattoirs) is an important strategy for improving farm income on two folds: first, selling directly in abattoirs helps to obviate unnecessary charges by middlemen and taxes in the open air markets. Moreover, farmers selling in abattoirs might be able to obtain better value for their cattle; given that some abattoirs especially in peri-urban areas pay on the basis of live weight of cattle. In contrast, cattle prices in open air markets are usually based on subjective assessments, e.g., height measurement or age of cattle, and might be considerably lower (Randeny, Kristjanson, Ruto, Scarpa, \& Wakhungu, 2006). 
In order to select possible explanatory variables for the binary logit regression, multicollinearity was tested by computing variance inflation factors (VIF) for each of the farm characteristics in Table 1. This involved estimation of 'artificial' ordinary least squares (OLS) regressions between each of the farm characteristics as the 'dependent' variable with the rest as independent variables. The VIF for each regression is calculated as:

$$
V I F_{i}=\frac{1}{1-R_{i}^{2}}
$$

where $R_{i}^{2}$ is the $R^{2}$ of the artificial regression with the $i^{\text {th }}$ independent variable as a 'dependent' variable.

Following Maddala (2000), variables that had $\operatorname{VIF}<5$ were considered to have no multicollinearity; hence they were selected for inclusion in the binary logit regression. The selected variables are explained in Table 2 .

Table 2. Description of variables in the binary logit model

\begin{tabular}{llc}
\hline Variable & Description of the variable & Expected signs \\
\hline LOCA & Location of farm (1=peri-urban, $0=$ rural $)$ & + \\
EXPR & Experience in cattle farming (number of years $)$ & + \\
FAMZ & Farm size in acres & + \\
MKT & Main market for cattle (1=abattoir, $0=$ open air market or others $)$ & \pm \\
AGRO & Agro-pastoralist production system (1=yes, 0 otherwise $)$ & + \\
NOM & Nomadic production system (1=yes, 0 otherwise $)$ & + \\
RAN & Ranch production system $(1=$ yes, 0 otherwise $)$ & + \\
EXTS & Access to extension service in the past one year $(1=$ yes, 0 otherwise $)$ & + \\
INCOM & Monthly household income is over Kshs 20 000 $(1=$ yes, 0 otherwise $)$ & + \\
GEND & Gender of household head $(1=$ male, 0 female $)$ & \pm \\
\hline
\end{tabular}

Notes: ranch is used as the base category in the model to avoid incidence of dummy variable trap.

Further, partial correlation coefficients were computed for the selected variables. The correlation analysis confirmed that there was no multicollinearity; although some of the variables are generally correlated, all partial correlation coefficients are less than 0.5. Both partial correlation coefficients and VIFs are shown in Table 3. Compared to rural farmers, peri-urban farmers are likely to be agro-pastoralists or ranchers, they have relatively smaller farms, sell mostly in abattoirs and have higher income. Nomads and/or farmers who receive livestock extension services are relatively experienced in cattle production. Access to extension is mostly by male household heads, agro-pastoralists, and those who sell in abattoirs and have higher income. Moreover, male household heads, especially ranchers and those with access to extension services have relatively big farms. Finally, ranchers and other farmers who sell in abattoirs have relatively higher income than other farm types.

Table 3. Partial correlation coefficients and variance inflation factors for explanatory variables

\begin{tabular}{|c|c|c|c|c|c|c|c|c|c|c|}
\hline & \multicolumn{9}{|c|}{ Correlation coefficients } & \multirow[t]{2}{*}{ VIF } \\
\hline & LOCA & EXPR & FAMZ & EXTS & GEND & MKT & NOM & AGRO & INCOM & \\
\hline LOCA & 1.00 & & & & & & & & & 1.1 \\
\hline EXPR & -0.06 & 1.00 & & & & & & & & 1.0 \\
\hline FARMZ & $-0.12 * *$ & 0.05 & 1.00 & & & & & & & 1.3 \\
\hline EXTS & 0.05 & $0.13^{* *}$ & $0.20^{* * *}$ & 1.00 & & & & & & 1.3 \\
\hline GEND & 0.01 & 0.05 & $0.16^{* * *}$ & $0.15^{* * *}$ & 1.00 & & & & & 1.1 \\
\hline MKT & $0.24 * * *$ & 0.05 & 0.03 & $0.19^{* * *}$ & $0.19^{* * *}$ & 1.00 & & & & 1.2 \\
\hline NOM & $-0.13 * *$ & $0.13^{* *}$ & $-0.09 *$ & -0.06 & -0.11 & $-0.17 * * *$ & 1.00 & & & 2.6 \\
\hline AGRO & $0.11 *$ & $-0.12 * *$ & $-0.28^{* * *}$ & $0.18^{* * *}$ & -0.06 & 0.02 & $-0.61 * * *$ & 1.00 & & 2.9 \\
\hline INCOM & $0.14 * *$ & -0.01 & $0.33^{* * *}$ & $0.35^{* * *}$ & $0.20^{* * *}$ & $0.12^{* *}$ & $-0.22 * * *$ & $-0.28 * *$ & 1.00 & 1.7 \\
\hline
\end{tabular}

Notes: Statistical significance levels: $* * * 1 \% ; * * 5 \% ; * 10 \%$. 


\subsection{Determinants of Farmers' Choice of Improved Cattle Breeds}

Parameter estimates (coefficients and marginal effects) from the binary logit model are shown in Table 4. The coefficient values explain the general influence of each variable on the probability of choosing improved cattle, while the marginal effects measure the actual effect of instantaneous changes in each of the explanatory variables on farmers' decision to adopt improved cattle.

The estimated coefficients show that peri-urban location (LOCA) is significant in influencing farmers to adopt improved cattle. This can be explained by proximity to inputs sellers (agrovet shops) and other facilities that are necessary in livestock production. Further, as noted by Stifel and Minten (2008), farmers in less remote areas have relatively better access to technology and infrastructure, and they might be expected to adopt and use new production methods more efficiently. In addition, consistent with the view of Ortega, Ward, and Andrew (2004) a farmers' hands-on experience (EXPR) in livestock production is an important accumulated skill that is useful for adoption and management of improved technology, for instance better cattle breeds. Further, farmers with relatively larger farms (FAMZ) are more likely to adopt improved cattle; perhaps due to their ability to grow more fodder (Sharma, Leung, \& Zaleski, 1999) or they might use the land as collateral in order to access credit and/or other inputs, considering high capital requirements for improved cattle production.

Sale of cattle in abattoirs (MKT) has a significant positive influence on farmers' adoption of improved cattle breeds. This might be explained by the fact that some abattoirs that offer relatively better prices in Kenya (especially those in peri-urban areas) have minimum live weight limits for purchased cattle. Therefore, following the notion of Detre et al. (2011) rational farmers are likely to adopt improved cattle breeds, in pursuit of markets that offer relatively higher income. However, as noted by Randeny et al. (2006) the number of abattoirs available might not be adequate to serve all cattle farmers in a particular locality. Moreover, weighing scales in some abattoirs might be faulty; hence depriving farmers a fair valuation of their cattle. Therefore, it appears reasonable to improve existing market channels, and open more avenues for selling cattle.

Consistent with earlier observations (see Table 1), the agro-pastoralists (AGRO) and ranchers who are typically sedentary farmers and operate diversified enterprises are more likely to adopt improved cattle than the nomads. Generally, enterprise competition exerts pressures on resources especially land and labour in agro-pastoralism and ranches. However, this might be considered as a blessing in disguise as it leads to intensification of production methods, for instance through zero-grazing or semi-zero grazing approaches (Gamba, 2006), which are more conducive for improved cattle breeds. In contrast, uncontrolled extensive grazing practised by nomads is relatively unsuitable for improved cattle breeds, as it would expose them to harsh tropical heat and disease stresses. Perhaps, this suggests that it is important to encourage sedentarisation of nomads in Kenya, for instance by development of long-term physical and social infrastructure in the ASALs as is the case in Uganda (Wurzinger, Okeyo, Semambo, \& Solkner, 2009).

As expected, higher income (INCOM) and access to livestock extension services (EXTS) have positive (though insignificant) influence on adoption of improved cattle. Perhaps, the effect of income is not significant in improved cattle adoption because most farmers with diversified enterprises (e.g., agro-pastoralists and ranchers) might invest relatively less in cattle production inputs (e.g., improved feeds, veterinary services etc.) either due to greater pressure from/preference for other 'highly profitable' enterprises such as horticulture. Moreover, these findings corroborate the observation by Lesorogol (2008) that Kenyan pastoralists derive considerable income from sale of livestock and part of their land, but spend much of it on consumption rather than investment on improving their livestock enterprises. In the case of dairy cattle farmers in high potential areas of Kenya, Murage and Ilatsia (2011) found that agro-ecological zone and access to markets were more important than household income, in influencing farmers' choice of breeding services.

Access to extension services was found to be insignificant in farmers' adoption decisions, perhaps due to inadequate frequency and quality of services offered by the extension providers; considering that the national extension system in Kenya is generally limited in scope due to insufficient number of professionally trained extension personnel (Oluoch-Kosura, 2010). Low remuneration of public extension staff in the ASALs also discourages them from working in such hardship areas; most of them often seek transfers to relatively endowed areas where they can easily access opportunities for further career enhancement. Moreover, private extension agents are expensive and largely target high potential areas where cash crops are grown and dairy farming is practised (Muyanga \& Jayne, 2006); hence beef cattle farmers in the dry ASALs do not receive timely and quality advisory services pertinent to improved cattle adoption. Finally, gender (GEND) is not a significant determinant of the uptake of improved cattle breeds. Thus, male or female farmers are likely to adopt improved beef cattle, conditional on provision of requisite services. 
The marginal effect estimates show that production system, market outlet and location of the farm have the highest influence on farmers' decisions to adopt improved cattle breeds. Being in an agro-pastoralist system would account for up to $39 \%$ of adoption of improved cattle, holding all other factors constant. Further, direct sale to abattoirs and being in a peri-urban location, respectively would contribute to about $22 \%$ and $15 \%$ of improved cattle adoption in the sample of Kenyan beef farmers. An increase in the farm size and experience in cattle production would increase adoption of improved cattle by less $1 \%$. It is important to develop relevant policies and support institutions that target the provision of services necessitated by the significant variables, in order to enhance adoption of improved cattle in the appropriate agro-climatic zones in the ASALs of Kenya.

Table 4. Binary logit estimates of determinants of farmers' adoption of improved beef cattle

\begin{tabular}{|c|c|c|c|c|}
\hline Variable & Coefficient $(\beta)$ & $\beta_{\mathrm{p} \text {-value }}$ & Marginal effect $\left(\beta_{\mathrm{m}}\right)$ & $\beta_{\mathrm{m}} \mathrm{p}$-value \\
\hline CONSTANT & $\begin{array}{c}-1.426^{* * *} \\
(0.539)\end{array}$ & 0.008 & $\begin{array}{c}-0.355^{* * *} \\
(0.135)\end{array}$ & 0.009 \\
\hline LOCA & $\begin{array}{c}0.611^{* *} \\
(0.310)\end{array}$ & 0.049 & $\begin{array}{c}0.148^{* *} \\
(0.073)\end{array}$ & 0.041 \\
\hline EXPR & $\begin{array}{l}0.023^{*} \\
(0.013)\end{array}$ & 0.089 & $\begin{array}{l}0.006^{*} \\
(0.003)\end{array}$ & 0.089 \\
\hline FAMZ & $\begin{array}{c}0.001 * * \\
(0.000)\end{array}$ & 0.046 & $\begin{array}{c}0.002^{* *} \\
(0.000)\end{array}$ & 0.046 \\
\hline MKT & $\begin{array}{c}0.907^{* * *} \\
(0.283)\end{array}$ & 0.001 & $\begin{array}{c}0.223 * * * \\
(0.067)\end{array}$ & 0.001 \\
\hline AGRO & $\begin{array}{c}1.657 * * * \\
(0.439)\end{array}$ & 0.001 & $\begin{array}{c}0.387 * * * \\
(0.091)\end{array}$ & 0.001 \\
\hline NOM & $\begin{array}{l}-0.125 \\
(0.426)\end{array}$ & 0.768 & $\begin{array}{l}-0.031 \\
(0.106)\end{array}$ & 0.769 \\
\hline EXTS & $\begin{array}{l}0.0426 \\
(0.289)\end{array}$ & 0.883 & $\begin{array}{c}0.011 \\
(0.072)\end{array}$ & 0.883 \\
\hline INCOM & $\begin{array}{c}0.017 \\
(0.354)\end{array}$ & 0.962 & $\begin{array}{c}0.004 \\
(0.088)\end{array}$ & 0.962 \\
\hline GEND & $\begin{array}{l}-0.391 \\
(0.299)\end{array}$ & 0.191 & $\begin{array}{l}-0.096 \\
(0.073)\end{array}$ & 0.184 \\
\hline
\end{tabular}

Notes: Standard errors are shown in parentheses. Statistical significance levels: ${ }^{* * *} 1 \% ; * * 5 \% ; * 10 \%$. McFadden pseudo- $\mathrm{R}^{2}=0.317$.

\section{Conclusions and Policy Implications}

This study applied a binomial (binary) logit model to investigate market and non-market factors that might influence adoption of improved beef cattle by farmers in arid and semi-arid lands (ASALs) in Kenya. The study contributes useful insights to development policy; cattle breed improvement programmes and necessary infrastructure for ultimate uptake of such technology by farmers. Further, the use of variance inflation factors to test for multicollinearity considerably improved the statistical robustness of variable selection for the logit model.

Results showed that half of farmers in the ASALs have adopted improved beef cattle. The main factors that significantly have a positive influence on adoption include operation of agro-pastoral and ranch production systems, direct sale of cattle in abattoirs as opposed to open air markets, location in a peri-urban area, possession of a large farm and experience in cattle production. These findings suggest that it is important to develop appropriate policies and institutional support services in order to improve the uptake of better cattle breeds. For instance, increased decentralisation of input supply systems and development of physical infrastructure (e.g., roads) in rural areas might improve farmers' access to requisite inputs; and hence promote their adoption of better cattle breeds to considerable levels like farmers in the peri-urban areas.

Moreover, improved infrastructure in rural and peri-urban areas would possibly increase farmers' access to abattoirs that offer relatively better prices. However, it is important to enhance monitoring of weights and scales 
used in abattoirs, and enforce punitive measures to deter any chances of using faulty weighing scales or other likely forms of exploitation of farmers in the marketing of live animals in abattoirs. To promote increased commercialisation of pastoralists' herds, there is need for concerted efforts by both public and private sectors to open more regular market outlets (e.g., cattle auction points and contract-based purchase arrangements) for supply in high-income population segments in domestic and/or export markets. At the local level, the government should harmonise and reduce charges on livestock sales in open air markets.

Further, it appears reasonable to encourage sedentarisation of nomads, for instance through long-term investments in water and pasture development. This would enable them to intensify production methods, for example by practising zero-grazing or semi-zero grazing that are relatively conducive to most improved cattle (especially exotic breeds) that are less tolerant to heat and disease challenges in tropical extensive grazing.

In addition, training of more extension workers should be prioritised in national institutions of higher education and research. Provision of necessary incentives (e.g., adequate hardship allowances and career improvement opportunities) should also be considered to encourage extension personnel to work effectively in the relatively dry and often marginalised pastoralist areas. Finally, beef cattle farmers should be trained on production of high quality fodder that is adapted to their respective agro-climatic zones. It is also important to promote peer-learning and sharing of livestock production experience among farmers, for instance through farmer field schools and farm-level workshops. Future research could provide more insights by investigating the role of public-private sector partnerships and pastoralist farmers in resource mobilisation for provision of requisite services for enhanced adoption of improved beef cattle breeds in the dry lands.

\section{References}

Aklilu, Y. (2002). An audit of the livestock marketing status in Kenya, Ethiopia and Sudan, Volume I. Pan African Programme for the Control of Epizootics. Nairobi: Organization for African Unity/Inter-African Bureau for Animal Resources (PACE, OAU/IBAR).

Allen, M., Kilpatrick, D., Armstrong, M., Briggs, R., Course, G., \& Perez, N. (2002). Multistage cluster sampling design and optimal sample sizes for estimation of fish discards from commercial trawlers. Fisheries Research, 55(1-3), 11-24. http://dx.doi.org/10.1016/165-7836(01)00308-3

African Union-Interafrican Bureau for Animal Resources [AU-IBAR] (2010). Framework for mainstreaming livestock in Comprehensive Africa Agriculture Development Programme (CAADP) pillars. Nairobi: AU-IBAR.

Bebe, B. O., Udo, H. M. J., Rowlands, G. J., \& Thorpe, W. (2003). Smallholder dairy systems in the Kenya highlands: breed preferences and breeding practices. Livestock Production Science, 82, 117-127. http://dx.doi.org/10.1016/S0301-6226(03)00029-0

Cramer, J. S. (1991). The Logit Model. An Introduction for Economists. London: Edward Arnold.

De Dios Jimenez, J, \& Salas-Velascos, M. (2000). Modeling educational choices. A binomial logit model applied to the demand for higher education. Higher Education, 40(3), 293-311.

Detre, J. D., Mark, T. D., Mishra, A., \& Adhikari, A. (2011). Linkage between direct marketing and farm income: A double-hurdle approach. Agribusiness, 27(1), 19-33. http://dx.doi.org/10.1002/agr.20248

Fratkin, E. (2001). East African pastoralism in transition: Maasai, Boran, and Rendile cases. African Studies Review, 44(3), 1-25. http://dx.doi.org/10.2307/525591

Gamba, P. (2006). Beef and dairy cattle improvement services: A policy perspective. Working paper No. 23. Nairobi: Tegemeo Institute of Agricultural Policy and Development.

Greene, W. H. (2003). Econometric Analysis (5th edn). New Jersey: Prentice Hall.

Greene, W. H. (2007). LIMDEP version 9.0/NLOGIT version 4.0 Econometric Modelling Guide, Econometric Software. New York: Plainview.

Greene, W. H., \& Hensher, D. A. (2009). Modeling ordered choices. New York: New York University.

Horppila, J., \& Peltonen, H. (1992). Optimizing sampling from trawl catches: Contemporaneous multistage sampling for age and length structures. Canadian Journal of Fisheries and Aquatic Science, 49(8), 1555-1559.

Irungu, P., Omiti, J. M., \& Mugunieri, L. G. (2006). Determinants of farmers' preference for alternative animal health service providers in Kenya: A proportional hazard application. Agricultural Economics, 35(1), 11-17. http://dx.doi.org/10.1111/j.1574-0862.2006.00134.x 
Kahi, A. K., Nitter, G., \& Gall, C. F. (2004). Developing breeding schemes for pasture based dairy production system in Kenya II. Evaluation of alternative objectives and schemes using a two-tier open nucleus and young bull system. Livestock Production Science, 88(1-2), 179-192.

Kahi, A. K., Thorpe, W., Nitter, G., Van Arendonk, J. A. M., \& Gall, C. F. (2000). Economic evaluation of crossbreeding for dairy production in a pasture based production system in Kenya. Livestock production Science, 65(1-2), 167-184. http://dx.doi.org/10.1016/S0301-6226(99)00154-2

Kavoi, M., Hoag, D., \& Pritchett, J. (2010). Measurement of economic efficiency for smallholder dairy cattle in the marginal zones of Kenya. Journal of Development and Agricultural Economics, 2(4), 122-137.

Kenya Institute for Public Policy Research and Analysis [KIPPRA]. (2009). Kenya economic report: Building a globally competitive economy. Nairobi: KIPPRA.

Lesorogol, C. K. (2008). Land privatization and pastoralists well-being in Kenya. Development and Change, 39(2), 309-331. http://dx.doi.org/10.1111/j.1467-7660.2007.00481.x

Maddala, G. S. (2000). Introduction to Econometrics (3rd edn). New Jersey: Prentice-Hall Inc.

McFadden, D. (1974). 'Conditional logit analysis of qualitative choice behavior', In P. Zarembka (Ed.), Frontiers in Econometrics (pp. 105-145). New York: Academic Press.

Ministry of Agriculture, \& Kenya Institute for Public Policy Research and Analysis [MoA\&KIPPRA] (2009). Kenya's agricultural sector data compendium. Nairobi: MoA\&KIPPRA. Retrieved from http://www2.kilimo.go.ke

Murage, A. W., \& Ilatsia, E. D. (2011). Factors that determine use of breeding services by smallholder dairy farmers in Central Kenya. Tropical Animal Health and Production, 43(1), 199-207. http://dx.doi.org/10.1007/s11250-010-9674-3

Musalia, L. M., Wangia, S. M. M., Shivairo, R. S., \& Vugutsa, V. (2010). Effect of policy change on the dairy production support services within the smallholder dairy farmers in Butere/Mumias and Kakamega districts of Western Kenya. African Journal of Agricultural Research, 5(8), 661-667.

Muyanga, M., \& Jayne, T. S. (2006). Agricultural extension in Kenya: Practice and policy lessons. Working Paper No. 26. Nairobi: Tegemeo Institute of Agricultural Policy and Development.

Oluoch-Kosura, W. (2010). Institutional innovations for smallholder farmers' competitiveness in Africa. African Journal of Agricultural and Resource Economics, 5(1), 227-242.

Omiti, J., \& Irungu, P. (2002). Institutional and policy issues relevant to pastoral development in Kenya. Discussion paper No. 031. Nairobi: Institute of Policy Analysis and Research (IPAR).

Orodho, A. B. (2002). Grassland and pasture crops: Country pasture/forage resource profile, Kenya. Retrieved from http://www.fao.org/ag/AGP/AGPC/doc/counprof/kenya.htm

Ortega, L., Ward, R. W., \& Andrew, C. (2004). Measuring technical efficiency in Venezuela: The dual-purpose cattle system (DPCS). EDIS document FE495, University of Florida, Gainesville, FL. Retrieved from http://edis.ifas.ufl.edu

Otieno, D. (2008). Determinants of Kenya's beef export supply. Discussion paper No. 85, ISBN: 9966777334. Nairobi: Kenya Institute for Public Policy Research and Analysis (KIPPRA). Retrieved from http://blds.ids.ac.uk/opaccf/detailed.cfm?RN=281990

Owango, M., Lukuyu, B., Staal, S. J., Kinyanjui, M., \& Njubi, D. (1998). Dairy cooperatives and policy reform in Kenya: Effects of livestock service and milk market liberalization. Food Policy, 23(2), 173-185. http://dx.doi.org/10.1016/S0306-9192(98)00027-X

Randeny, M., Kristjanson, P., Ruto, E., Scarpa, R., \& Wakhungu, J. (2006). Determinants of cattle prices in southern Kenya: Implications for breed conservation and pastoral marketing strategies. In J. G. McPeak, P. D. Little (Eds.), Pastoral Livestock Marketing in Eastern Africa: Research and Policy Challenges (pp. 89-107). Intermediate Technology Development Group (ITDG), Warwickshire.

Rege, J. E. O. (1998). Utilization of exotic germplasm for milk production in the tropics. Proceedings of the 6th World Congress on Genetics applied to Livestock Production, 25, 193-200.

Republic of Kenya. (2008a). Livestock production annual report for the year 2007, Kilifi District. Nairobi: Ministry of Livestock Development, Livestock Production Department. 
Republic of Kenya. (2008b). Livestock production annual report for the year 2007, Makueni District. Nairobi: Ministry of Livestock Development, Livestock Production Department.

Republic of Kenya. (2008c). Livestock production annual report for the year 2007, Taita Taveta District. Nairobi: Ministry of Livestock Development, Livestock Production Department.

Republic of Kenya. (2010). Kenya 2009 population and housing census results. Nairobi: Ministry of State for Planning, National Development and Vision 2030, Government printer.

Sadoulet, E., \& de Janvry, A. (1995). Quantitative Development Policy Analysis. Baltimore: John Hopkins University Press.

Sharma, K. R., Leung, P., \& Zaleski, H. M. (1999). Technical, allocative and economic efficiencies in swine production in Hawaii: A comparison of parametric and nonparametric approaches. Agricultural Economics, 20(1), 23-35. http://dx.doi.org/10.1016/S0169-5150(98)00072-3

Sombroek, W. C., Braun, H. M. H., \& van de Pouw, B. J. A. (1982). Explanatory soil map and agro-climatic zone map of Kenya. Report E1. Nairobi: National Agricultural Laboratories.

Stifel, D., \& Minten, B. (2008). Isolation and agricultural productivity. Agricultural Economics, 39(1), 1-15. http://dx.doi.org/10.1111/j.1574-0862.2008.00310.x

Tambi, N. E., Mukhebi, W. A., Maina, W. O., \& Solomon, H. M. (1999). Probit analysis of livestock producers' demand for private veterinary services in the high potential agricultural areas of Kenya. Agricultural Systems, 59(2), 163-176. http://dx.doi.org/10.1016/S0308-521X(98)00088-2

Thornton, P. K., Randall, B. B., Galvin, K. A., Burnsilver, S. B., Waithaka, M. M., Kuyiah, J., ... Herrero, M. (2007). Coping strategies in livestock-dependent households in east and southern Africa: A synthesis of four case studies. Human Ecology, 35(4), 461-476. http://dx.doi.org/10.1007/s10745-007-9118-5

Wilson, R. T. (2009). Devon red ruby cattle in Kenya. African Journal of Agricultural Research, 4(5), 553-555.

World Atlas (2011). Geographical map of Kenya. The World Atlas. Retrieved from http://africa.theworldatlas.net/kenya/map.html

Wurzinger, M., Okeyo, A. M., Semambo, D., \& Solkner, J. (2009). The sedentarisation process of the Bahima in Uganda: An emic view. African Journal of Agricultural Research, 4(10), 1154-1158.

Note 1. The logit model can be considered as a unique case of a general model of utility maximisation (Cramer, 1991). Greene \& Hensher (2009) note that the logistic distribution is preferred in applied work over the probit because of computational complexity arising from lack of a closed form for the normal cumulative density function on which the probit model is based. Empirical applications of the binomial logit model include its use in modelling educational degree choices (see De Dios Jimenez \& Salas-Velascos, 2000). 